\title{
Peculiarities of microbiocenosis in the upper and lower respiratory tract of clinically healthy calves and the calves with bronchopneumonia
}

\section{Peculiaridades da microbiocenose no trato respiratório superior e inferior de bezerros clinicamente saudáveis e bezerros com broncopneumonia}

\author{
Alekhin Yuriy Nikolaevich ${ }^{1} \mathbb{D}$, Zhukov Maksim Sergeevich ${ }^{1 *} \mathbb{D}$, Manzhurina Olga Alekseevna ${ }^{1} \mathbb{D}$, \\ Morgunova Valentina Ivanovna' 1 ]
}

'All-Russian Veterinary Research Institute of Pathology, Pharmacology and Therapy/ARVRIPP\&T, Voronezh, Russia

${ }^{*}$ Corresponding author: maxim.zhukoff2015@yandex.ru

Received in June 9, 2021 and approved in September 17, 2021

\begin{abstract}
Bovine respiratory diseases are widespread and present a multifactorial and variable etiology. However, several aspects of their origin remain understudied. Therefore, the objective of the present study was to investigate the effect of changes in calves' keeping conditions on their clinical state in terms of microbiocenosis in their respiratory tract. The study was conducted in the winter season, with 37 healthy calves, 5-6 months in age, which were transferred from calf barn number 1 with favorable conditions to calf barn number 2 having a similar design as that of the previous barn but with unfavorable microclimatic parameters (drafts, low temperature, and high humidity). Within 7-9 days after their transfer to the other barn by a veterinary specialist, $54.1 \%$ of the calves were diagnosed with catarrhal bronchopneumonia. On day 10, all animals were slaughtered and dissected. Mucus samples for bacteriological analysis were obtained from the mucous membrane of seven sections of the respiratory tract of animals. In all calves, the highest degree of contamination was observed in the first half of the ventral nasal passage ( $84.9 \pm 24.46 \%$ in healthy calves and $85.7 \pm 18.55 \%$ in sick calves). In healthy calves, the degree of contamination in the front of the choanae was lower by a factor of $56.2 \%(P=0.000059)$ compared to sick calves, and this value continued to decrease when moving toward the lower respiratory tract until the complete disappearance of the bacteria.
\end{abstract}

Index terms: Bovine; local immunity; desease therapy.

\begin{abstract}
RESUMO
As doenças respiratórias bovinas são generalizadas e apresentam etiologia multifatorial e variável. No entanto, vários aspectos de sua origem permanecem pouco estudados. Portanto, o objetivo do presente estudo foi investigar o efeito das mudanças nas condições de criação de bezerros sobre seu estado clínico em termos de microbiocenose em seu trato respiratório. O estudo foi conduzido na temporada de inverno, com 37 bezerros saudáveis, de 5 a 6 meses de idade, que foram transferidos do estábulo número 1 com condições favoráveis para o celeiro de bezerros número 2 tendo um desenho semelhante ao do celeiro anterior, mas com parâmetros microclimáticos desfavoráveis (correntes de ar, baixa temperatura e alta umidade). Dentro de 7-9 dias após sua transferência para o outro celeiro por um especialista veterinário, $54,1 \%$ dos bezerros foram diagnosticados com broncopneumonia catarral. No dia 10 , todos os animais foram abatidos e dissecados. Amostras de muco para análise bacteriológica foram obtidas da membrana mucosa de sete seções do trato respiratório de animais. Em todos os bezerros, o maior grau de contaminação foi observado na primeira metade da passagem nasal ventral $(84,9 \pm 24,46 \%$ em bezerros saudáveis e $85,7 \pm 18,55 \%$ em bezerros doentes). Em bezerros saudáveis, o grau de contaminação na frente das coanas foi menor por um fator de $56,2 \%(P=0,000059)$ em comparação com bezerros doentes, e esse valor continuou a diminuir ao se mover em direção ao trato respiratório inferior até o desaparecimento completo das bactérias.
\end{abstract}

Termos para indexação: Bovino; imunidade local; terapia de doença.

\section{INTRODUCTION}

Respiratory diseases are widespread among young cattle, becoming the most common cause of cattle death at feedlots (Robert; Douglas; Amelia, 2020). Respiratory diseases lead to a decrease in the efficiency of feeding and the quality of carcasses, as well as an increase in treatment costs, all of which ultimately lead to a decrease in business efficiency (Brooks et al., 2011). Respiratory diseases present a multifactorial and variable etiology, the knowledge of which is the main requirement of designing a therapy for these diseases (Pratelli et al., 2020; Calvin; Brian, 2020). It is reported that violations 
in the microclimatic parameters, particularly temperature and humidity, play an important role in the occurrence of respiratory diseases (Walker et al., 2012; Brscic et al., 2012; Roland et al., 2016). Although animals are adaptable to several unfavorable climatic factors, extreme changes in the climate may lead to various stresses and an imbalance in the defense mechanisms of the body, which is followed by the activation of pathogenic microflora and the development of pathology, particularly in the respiratory system (Roy; Collier, 2012; Roland, 2016; França Dias De Oliveira et al., 2016; Franco et al., 2019). However, under identical environmental risks, certain calves fall ill while other do not, and this difference, according to certain authors, arises due to the different state of microbiocenosis in the respiratory tracts of different animals (Volkmann; Sanftleben; Kemper, 2015; Nicola et al., 2017; Lanaspa et al., 2017; Zeineldin; Lowe; Aldridge, 2019; Timsit et al., 2020). Therefore, it is speculated that the phenomenon of respiratory microbiocenosis is an important nosogenetic mechanism, and its modeling is a promising prevention method against respiratory diseases in cattle. In this context, the present study was aimed to investigate the effect of changes in the keeping conditions of calves on the clinical state of microbiocenosis of their upper and lower respiratory tracts.

\section{MATERIAL AND METHODS}

\section{Experiment}

The experimental procedures in the present study were conducted in compliance with the rules of humane treatment of animals. Animal slaughter was conducted in accordance with the existing rules and regulations (The council of the European Union, 1993; The European Parliament and the council of the European Union, 2010).

The study was conducted in December 2018 at an industrial complex for fattening cattle located in the Voronezh region, Russia. An analog method was adopted to select 37 clinically healthy calves of age 5-6 months and body weight in the range of $162.5 \pm 2.50 \mathrm{~kg}$. The animals were fed a complete and balanced diet (National Research Council, 2016) throughout the experimental period. Initially, the calves were kept in a tie-stall barn (no. 1) for 30 days. This barn was $9 \times 30 \mathrm{~m}$ in dimensions and was divided into different sections of 5-7 animals each. The barn had a mechanical ventilation system with a supply of heated air that ensured an optimal air temperature and a 4.5 -fold replacement of air in the premises within an hour. The floor of the barn was wooden with a straw mat and an area of $2.0 \mathrm{~m}^{3}$ for each animal. In this calf barn, the animals were kept under optimal environmental conditions, which are provided in Table 1. After 30 days, the calves were transferred to another calf barn (barn no. 2), which had a similar design, although the ventilation was natural and unregulated with no heating system for the circulating air. In this calf barn, the animals were kept under unfavorable environmental conditions, which are provided in Table 1.

Table 1: Microclimatic indicators $(M \pm S D)$ in the two calf barns.

\begin{tabular}{ccr}
\hline \multirow{2}{*}{ Air indicators } & \multicolumn{2}{c}{ Keeping conditions } \\
\cline { 2 - 3 } & Comfortable & Unfavorable \\
\hline Temperature, ${ }^{\circ} \mathrm{C}$ & $18.71 \pm 3.696$ & $6.51 \pm 1.540$ \\
Relative humidity, \% & $61.03 \pm 9.302$ & $90.50 \pm 8.008$ \\
Rate of motion, $\mathrm{m} / \mathrm{s}$ & $0.22 \pm 0.018$ & $0.70 \pm 0.072$ \\
\hline
\end{tabular}

The animals were kept in the calf barn no. 2 for 10 days, after which they were slaughtered in a slaughterhouse. The autopsy was conducted using the generally accepted method, observing all rules of personal and public safety (Mansour; Wilhite; Rowe, 2017).

\section{Animals}

The calves included in the present study were born through spontaneous calving from Holstein cows. None of the calves exhibited any signs of deformity and perinatal pathology. In the first few minutes of its life, each calf was allowed to be licked by its mother, following which it was placed into a thermal cage $\left(38.5-39.5^{\circ} \mathrm{C}\right)$ for $2 \mathrm{~h}$ for artificial drying. Subsequently, the calf was kept in an individual cage inside a prophylactorium calf house, where the air temperature was $18-25^{\circ} \mathrm{C}$, and the relative humidity was in the range of $60 \%-64 \%$. The animals were kept in these individual cages until they reached the age of 2 months. Afterward, the animals were kept in small-group (5-7 animals) cages for 4 months. In the first hour after birth, the newborns were fed $2 \mathrm{~L}$ of colostrum (density $1.048-1.053 \mathrm{~g} / \mathrm{cm}^{3}$ ) using a nipple drinking bottle. The animals were fed the colostrum milk from their respective mothers for another 7 days, after which they were fed bulk milk for 65 days. At the age of $9-10$ days, the animals were fed hay, although they were being fed specialized mixed fodders from the age of 5-7 days. The diet of animals older than 66 days was formulated in accordance with the existing feeding recommendations by the National Research Council (2016). This diet consisted of hay, corn 
silage, soybean cake, crushed corn and barley, minerals, and vitamins. Liquids were fed using the open-type drinkers that received water at a temperature range of $+5^{\circ} \mathrm{C}$ to $+7^{\circ} \mathrm{C}$, following all sanitary and hygiene requirements. At the age of 90 days, the animals were injected with the Bovi-Shield Gold FP 5 L5 vaccine (Zoetis, LLC. USA), two injections administered at an interval of 3-4 weeks.

\section{Zohygienic study}

Temperature, relative humidity, and airflow rate were measured using a portable multifunctional weather station Tenmars TM-414 (Tenmars, Taiwan). The measurements were undertaken at 6 places within the calf barn at a height of $0.7-0.9 \mathrm{~m}$ with respect to the floor.

\section{Clinical studies}

In the entire duration of the experiment (40 days), the animals were under the constant supervision of a certified veterinary specialist. The clinical assessments included the evaluation of the general state, appetite, respiratory rate (RR), heart rate (HR), body temperature (T), color of the nasal mucosa, the presence and characteristics of the nasal discharge and coughing, and the sounds during the percussion and auscultation of the chest (Gaeta et al., 2018).

\section{Laboratory research}

\section{Laboratory study}

The postmortem examination of the slaughtered animals involved obtaining biomaterial samples from the surface of mucous membranes at seven regions in the respiratory tract: $3-4 \mathrm{~cm}$ from the ventral nasal passage (R1); 7-8 cm from the ventral nasal passage (R2); in the ventral nasal passage, in front of the choanae (R3); in the trachea, $2-3 \mathrm{~cm}$ from the larynx (P4); in the trachea, between the tracheal bronchus and the bifurcation (R5); in the main bronchus, $4 \mathrm{~cm}$ from the tracheal bifurcation (R6); and in the middle lobe bronchus (R7). Sample collection was performed using sterile cotton swabs (Sterile Cotton Swab in screw-capped polypropylene tubes, cotton bud w/polypropylene size $75 \times 12 \mathrm{~mm}$ in diameter; HiMedia Laboratories Pvt. Ltd., India). After collection, the sample was placed inside a dry sterile disposable tube containing $800 \mu \mathrm{L}$ of saline. The biological material was then delivered, inside a thermocontainer, to the Laboratory of Bacteriology within $2 \mathrm{~h}$ of collection. Microbiological evaluations were conducted using conventional methods, commercial culture media, test systems, and diagnostic kits (Quinn et al., 2011). The morphological and tinctorial characteristics of the isolated bacteria were analyzed in a smear under a light microscope. The culture properties of the isolated bacteria were assessed by analyzing the nature of bacterial growth in conventional, special, and differential diagnostic media. The microorganisms were identified using Bergey's Manual of Determinative Bacteriology (Bergey et al., 1984).

\section{Statistical analysis}

The obtained result data were subjected to mathematical and statistical processing using the Statistica v6.1 software. The percentage of each microorganism (PM) and the average percentage of the respiratory tract contamination (APCP) were calculated using the following equations:

$P M=A b a c / A n * 100$

where 'Abac' denotes the number of animals in which the presence of a specific bacterium was detected and 'An' denotes the number of animals analyzed.

$A P C P=\sum(b * 100 / a) / n$

In the above equation, a denotes the number of bacterial species detected in a particular region of the respiratory tract, $\mathrm{b}$ denotes the total number of isolated bacterial species, and $\mathrm{n}$ denotes the number of animals in the group.

In addition, the arithmetic mean (M) and standard deviation (SD) were calculated. The differences between the experimental groups were evaluated using Student's t-test. The presence and strength of the relationship between two parameters were determined based on Spearman's rank correlation coefficient by calculating the correlation coefficient $r$ and constructing the correlation matrix.

\section{RESULTS AND DISCUSSION}

The clinical examination of calves $(n=37)$ prior to being transferred to calf barn no. 2 included the determination of the following indicators of healthy animals: general state - balanced; appetite - normal; RR $-20.4 \pm 1.50$ respiratory movements per minute; HR $79.2 \pm 2.17$ beats per minute; $\mathrm{T}-38.7 \pm 0.42{ }^{\circ} \mathrm{C}$; color of the nasal mucosa - pink; abnormal discharges from the nose - no; and pathological changes in sounds during the percussion and auscultation of the chest - detected. 
In 17 animals, during their stay in calf barn no. 2, no significant changes were observed in the above-stated clinical parameters. On Day 9, the general state of these animals was balanced, their appetite was normal, RR was $20.4 \pm 3.50$ respiratory movements per minute, HR was $82.3 \pm 2.83$ beats per minute, $\mathrm{T}$ was $38.9 \pm 0.13{ }^{\circ} \mathrm{C}$, color of the nasal mucous membrane was pink, there were no abnormal discharges from the nose, and no pathological changes in sounds were detected during the percussion and auscultation of the chest. Therefore, these 17 calves remained clinically healthy during their stay under unfavorable conditions for 10 days.

In 20 animals, 3-4 days after their transfer to calf barn no. 2 , the following signs of respiratory pathology appeared: increased respiratory rate (to $26.0 \pm 2.32 / \mathrm{min}$ ), coughing, sneezing, and lacrimation. The disease progressed over the next 5-6 days, and on Day 9, these animals were diagnosed with the symptoms of catarrhal bronchopneumonia (Gaeta et al., 2018, Zhukov; Alekhin, 2018): general state-depressed; food intake - decreased; dyspnea; polypnea $(31.5 \pm 1.85 /$ $\mathrm{min})$; tachycardia ( $96.8 \pm 3.07 / \mathrm{min})$; fever $(\mathrm{T}-39.6 \pm 0.025$ ${ }^{\circ} \mathrm{C}$ ); color of the nasal mucosa - cyanotic; nasal discharges - mucopurulent; paroxysmal productive cough; dull sound upon percussion of certain parts of the chest; fine bubbling rales upon auscultating certain regions of the chest.

However, the autopsy and examination of slaughtered healthy animals did not reveal any pathological changes. In the biomaterial obtained from the surface of the mucous membrane at the beginning and middle of the ventral nasal passage of these animals, presence of isolated vegetative forms of seven species of bacteria, namely, Bacillus subtilis, Enterococcus faecium, Enterococcus faecalis, Staphylococcus epidermidis, Escherichia coli, Pasteurella multocida, and Streptococcus bovis, was detected. In the samples retrieved from the choanal region, the same microorganisms were detected, although the frequency of their occurrence had begun decreasing, while Enterococcus faecium and Enterococcus faecalis had completely disappeared (Table 2).

In the samples retrieved from the surface of the trachea and bronchi of slaughtered clinically healthy calves, the vegetative forms of the majority of the abovestated microorganisms were absent, with the exception of Staphylococcus epidermidis, which was isolated from the mucous membrane at the beginning of the trachea in $11.8 \%$ of the slaughtered animals (Table 3 ).

Table 2: Degree of incidence of microorganism species in the upper respiratory tract of clinically healthy calves and the calves with bronchopneumonia.

\begin{tabular}{|c|c|c|c|c|}
\hline \multirow[t]{2}{*}{ Regions } & \multirow[t]{2}{*}{ Name of bacteria } & $\begin{array}{l}\text { Healthy } \\
(n=17)\end{array}$ & $\begin{array}{l}\text { Bronchopneumonia } \\
\qquad(\mathrm{n}=20)\end{array}$ & \multirow[t]{2}{*}{ P-value } \\
\hline & & $\mathrm{PM}, \%$ & $\mathrm{PM}, \%$ & \\
\hline R1 & $\begin{array}{l}\text { B. subtilis } \\
\text { E. faecium } \\
\text { E. faecalis } \\
\text { S. epidermidis } \\
\text { E. coli } \\
\text { P. multocida } \\
\text { S. bovis }\end{array}$ & $\begin{array}{c}82.3 \\
88.2 \\
100 \\
100 \\
100 \\
82.3 \\
100\end{array}$ & $\begin{array}{r}75 \\
75 \\
100 \\
100 \\
100 \\
80 \\
95\end{array}$ & $\begin{array}{l}0.600343 \\
0.319072 \\
0.909050 \\
0.909050 \\
0.909050 \\
0.860371 \\
0.364879\end{array}$ \\
\hline $\mathrm{R} 2$ & $\begin{array}{l}\text { B. subtilis } \\
\text { E. faecium } \\
\text { E. faecalis } \\
\text { S. epidermidis } \\
\text { E. coli } \\
\text { P. multocida } \\
\text { S. bovis }\end{array}$ & $\begin{array}{c}82.3 \\
70.6 \\
70.6 \\
100 \\
100 \\
70.6 \\
100\end{array}$ & $\begin{array}{r}50 \\
75 \\
100 \\
100 \\
100 \\
80 \\
95\end{array}$ & $\begin{array}{l}0.040918 \\
0.771063 \\
0.008104 \\
0.909050 \\
0.909050 \\
0.519514 \\
0.364879\end{array}$ \\
\hline R3 & $\begin{array}{l}\text { B. subtilis } \\
\text { E. faecium } \\
\text { E. faecalis } \\
\text { S. epidermidis } \\
\text { E. coli } \\
\text { P. multocida } \\
\text { S. bovis }\end{array}$ & $\begin{array}{c}47.1 \\
0 \\
0 \\
88.2 \\
47.1 \\
29.4 \\
11.8\end{array}$ & $\begin{array}{r}50 \\
45 \\
75 \\
100 \\
100 \\
80 \\
60\end{array}$ & $\begin{array}{l}0.863205 \\
0.000904 \\
0.000000 \\
0.121225 \\
0.000051 \\
0.001298 \\
0.001812\end{array}$ \\
\hline
\end{tabular}


Table 3: Degree of incidence of microorganism species in the lower respiratory tract of clinically healthy calves and the calves with bronchopneumonia.

\begin{tabular}{|c|c|c|c|c|}
\hline \multirow[t]{2}{*}{ Regions } & \multirow[t]{2}{*}{ Name of bacteria } & $\begin{array}{l}\text { Healthy } \\
(n=17)\end{array}$ & $\begin{array}{l}\text { Bronchopneumonia } \\
\qquad(\mathrm{n}=20)\end{array}$ & \multirow[t]{2}{*}{ P-value } \\
\hline & & $\mathrm{PM}, \%$ & $\mathrm{PM}, \%$ & \\
\hline R4 & $\begin{array}{l}\text { B. subtilis } \\
\text { E. faecium } \\
\text { E. faecalis } \\
\text { S. epidermidis } \\
\text { E. coli } \\
\text { P. multocida } \\
\text { S. bovis }\end{array}$ & $\begin{array}{c}0 \\
0 \\
0 \\
11.8 \\
0 \\
0 \\
0\end{array}$ & $\begin{array}{r}50 \\
45 \\
75 \\
100 \\
100 \\
80 \\
40 \\
\end{array}$ & $\begin{array}{l}0.000303 \\
0.000904 \\
0.000000 \\
0.000000 \\
0.000000 \\
0.000000 \\
0.002391\end{array}$ \\
\hline R5 & $\begin{array}{l}\text { B. subtilis } \\
\text { E. faecium } \\
\text { E. faecalis } \\
\text { S. epidermidis } \\
\text { E. coli } \\
\text { P. multocida } \\
\text { S. bovis }\end{array}$ & $\begin{array}{l}0 \\
0 \\
0 \\
0 \\
0 \\
0 \\
0 \\
\end{array}$ & $\begin{array}{r}50 \\
45 \\
75 \\
100 \\
90 \\
80 \\
40 \\
\end{array}$ & $\begin{array}{l}0.000303 \\
0.000904 \\
0.000000 \\
0.000000 \\
0.000000 \\
0.000000 \\
0.002391\end{array}$ \\
\hline $\mathrm{R} 6$ & $\begin{array}{l}\text { B. subtilis } \\
\text { E. faecium } \\
\text { E. faecalis } \\
\text { S. epidermidis } \\
\text { E. coli } \\
\text { P. multocida } \\
\text { S. bovis }\end{array}$ & $\begin{array}{l}0 \\
0 \\
0 \\
0 \\
0 \\
0 \\
0\end{array}$ & $\begin{array}{r}40 \\
40 \\
70 \\
100 \\
90 \\
100 \\
50\end{array}$ & $\begin{array}{l}0.002391 \\
0.002391 \\
0.000001 \\
0.000000 \\
0.000000 \\
0.000000 \\
0.000303\end{array}$ \\
\hline R7 & $\begin{array}{l}\text { B. subtilis } \\
\text { E. faecium } \\
\text { E. faecalis } \\
\text { S. epidermidis } \\
\text { E. coli } \\
\text { P. multocida } \\
\text { S. bovis }\end{array}$ & $\begin{array}{l}0 \\
0 \\
0 \\
0 \\
0 \\
0 \\
0\end{array}$ & $\begin{array}{r}30 \\
25 \\
70 \\
100 \\
100 \\
100 \\
35\end{array}$ & $\begin{array}{l}0.012752 \\
0.026584 \\
0.000001 \\
0.000000 \\
0.000000 \\
0.000000 \\
0.005742\end{array}$ \\
\hline
\end{tabular}

The results of the autopsy and examination of slaughtered sick animals confirmed the diagnosis of catarrhal-purulent bronchopneumonia, which was characterized by diffuse areas of compaction that were grayish-red in color, along with catarrhal-purulent and purulent exudate from the bronchi and bronchioles on the excised surface. Nasopharyngitis, characterized by diffuse hyperemia of the conjunctiva and swelling of the nasopharynx, was also observed.

In the case of slaughtered sick animals, Bacillus subtilis, Enterococcus faecium, Enterococcus faecalis, Staphylococcus epidermidis, Escherichia coli, Pasteurella multocida, and Streptococcus bovis were isolated from the biomaterial obtained from the surface of the mucous membrane at the beginning and middle of the ventral nasal passage. Moreover, in the first two sampling points, no significant difference existed in comparison to the clinically healthy animals. However, in the ventral nasal passage in front of the choanae in the calves with bronchopneumonia, a significant increase, compared to healthy animals, was observed in the incidence of various microorganism species: 45\% increase in Enterococcus faecium, 75\% increase in Enterococcus faecalis, $52.9 \%$ increase in Escherichia coli, 50.6\% increase in Pasteurella multocida, and 48.2\% increase in Streptococcus bovis. In these animals, along the entire analyzed portion of the respiratory tract, the microflora composition was represented by seven types of bacteria that had been previously isolated from the upper respiratory tract. However, the incidence of certain bacteria decreased when moving toward the middle-diameter bronchi. The frequency of occurrence of Bacillus subtilis and Enterococcus faecium decreased by $20 \%$, while that of Streptococcus bovis decreased by $25 \%$, compared to the frequency of their occurrence in the initial part of the trachea. However, these decreases in the values were insignificant $(\mathrm{P}>0.05)$. 
When plotting the average percentage of contamination of the respiratory tract regions, it was found that the highest degree of contamination was found on the mucous membrane of the first half of the ventral nasal passage, both in animals with bronchopneumonia and in healthy ones. However, in healthy calves in the region located in front of the choanae, the APCP indicator sharply decreased from $84.9 \pm 24.46 \%$ to $31.9 \pm 24.52 \%$ $(\mathrm{p}=0.0000)$ and then tended to zero (Figure 1). In calves with bronchopneumonia in this region, there was also a decrease in APCP from $85.7 \pm 18.55 \%$ to $72.8 \pm 29.27 \%$ $(\mathrm{p}=0.1042)$, and this level of the degree of contamination did not change significantly in further regions of the respiratory tract.

In order to determine the strength of the effect of the degree of microbial contamination in one region of the respiratory tract on the degree of contamination in the other regions of the respiratory tract in healthy calves and the calves with bronchopneumonia, the Spearman's rank correlation coefficient analysis was performed, and the correlation matrix was plotted. It was revealed that in clinically healthy calves, there was a significant direct correlation of high and medium strength [evaluated using the Chaddock scale] among the different regions of the upper respiratory tract evaluated in the present study (Table 4).

However, the strength decreased when moving toward the lower regions of the respiratory tract until it disappeared completely. In the calves with bronchopneumonia, a significant direct correlation of high strength [evaluated using the Chaddock scale] existed among all the regions of the respiratory tract.
Furthermore, the strength of the effect of bacterial presence in the respiratory tract on the probability of developing the respiratory pathology was analyzed. It was revealed that when the vegetative forms of bacteria were present in the ventral nasal passage, no reliable correlation of medium and high strength existed.

However, when Enterococcus faecium, Escherichia coli, Pasteurella multocida, and Streptococcus bovis were present in the front of the choanae in the ventral nasal passage, a significant correlation of medium strength was observed, while a correlation of high strength was observed for the presence of Enterococcus faecalis. When Bacillus subtilis, Enterococcus faecium, and Streptococcus bovis were detected in the lower regions of the respiratory tract, an average strength of the effect of developing respiratory diseases was observed, while a strong correlation on the Chaddock scale was observed for Enterococcus faecalis, Staphylococcus epidermidis, Escherichia coli, and Pasteurella multocida (Table 5).

In order to understand the importance of the state of microbiocenosis in the respiratory tract in relation to respiratory diseases in cattle, the present study aimed at exploring the peculiarities of microbiocenosis in the upper and lower respiratory tract in clinically healthy calves and the calves with bronchopneumonia. The data obtained in the present study demonstrated that the upper respiratory tract of both healthy calves and calves with bronchopneumonia contained a high percentage of contamination with microorganisms, including Bacillus subtilis, Enterococcus faecium, Enterococcus faecalis, Staphylococcus epidermidis, Escherichia coli, Pasteurella multocida, and Streptococcus bovis.

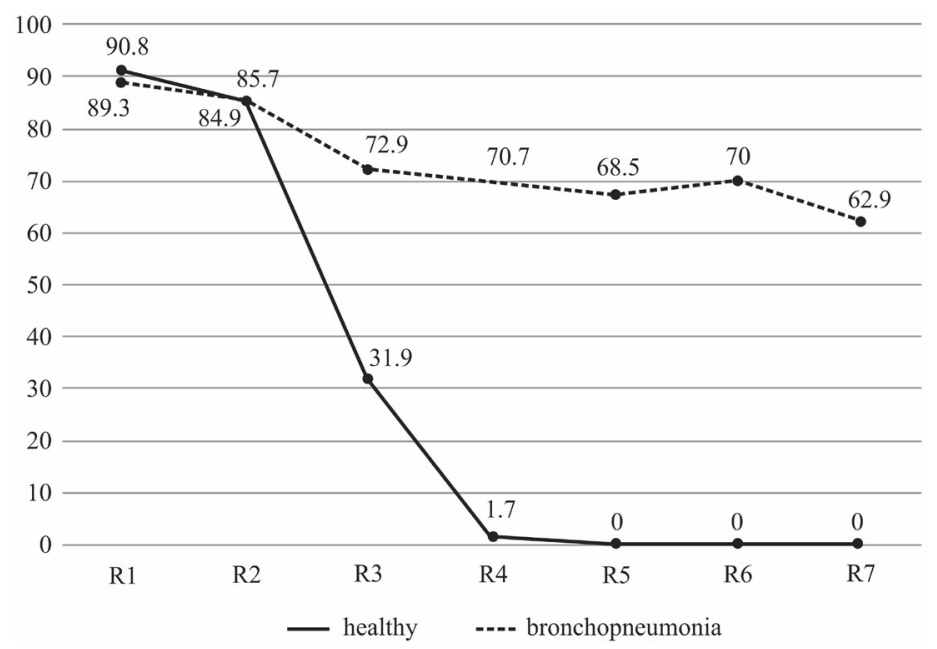

Figure 1: The average percentage of contamination in different regions of the respiratory tract in healthy calves and the calves with catarrhal-purulent bronchopneumonia. 
Table 4: Strength of the effect of the degree of contamination in certain regions of the respiratory tract on the degree of contamination in the other regions of the respiratory tract in healthy calves (A) and the calves with bronchopneumonia (B).

\begin{tabular}{|c|c|c|c|c|c|c|c|c|}
\hline Regions & Groups & R1 & R2 & R3 & R4 & R5 & R6 & R7 \\
\hline \multirow{2}{*}{ R1 } & A & - & $0.82 *$ & 0.61 * & $0.17 *$ & & & \\
\hline & B & - & $0.82 *$ & $0.79 *$ & $0.78 *$ & $0.79 *$ & $0.79 *$ & $0.68 *$ \\
\hline \multirow{2}{*}{ R2 } & $A$ & $0.82^{*}$ & - & $0.68 *$ & 0.23 & & & \\
\hline & B & $0.82 *$ & - & $0.97 *$ & $0.95 *$ & $0.96 *$ & $0.95 *$ & $0.84 *$ \\
\hline \multirow{2}{*}{ R3 } & A & 0.61 * & $0.68 *$ & - & $0.58 *$ & & & \\
\hline & B & $0.79 *$ & $0.97 *$ & - & $0.98 *$ & $0.98 *$ & $0.96 *$ & $0.88^{*}$ \\
\hline \multirow{2}{*}{ R4 } & A & 0.17 & 0.23 & $0.58^{*}$ & - & & & \\
\hline & B & $0.78^{*}$ & $0.95 *$ & $0.98 *$ & - & $0.99 *$ & $0.98 *$ & $0.89 *$ \\
\hline \multirow{2}{*}{ R5 } & $A$ & & & & & - & & \\
\hline & B & $0.79 *$ & $0.96 *$ & $0.98 *$ & $0.99 *$ & - & $0.99 *$ & $0.87^{*}$ \\
\hline \multirow{2}{*}{$\mathrm{R} 6$} & A & & & & & & - & \\
\hline & B & $0.76^{*}$ & $0.95 *$ & $0.96 *$ & $0.98 *$ & $0.99 *$ & - & $0.89 *$ \\
\hline \multirow{2}{*}{ R7 } & $A$ & & & & & & & - \\
\hline & B & $0.68 *$ & $0.84^{*}$ & $0.88 *$ & $0.89 *$ & $0.87 *$ & $0.89 *$ & - \\
\hline
\end{tabular}

Note: ${ }^{*} \mathrm{P}<0.05$.

Table 5: The strength of the effect of microbial presence in different regions of the respiratory tract on the probability of developing the respiratory pathology.

\begin{tabular}{cccccccl}
\hline Regions & $\mathrm{R} 1$ & $\mathrm{R} 2$ & $\mathrm{R} 3$ & $\mathrm{R} 4$ & $\mathrm{R} 5$ & $\mathrm{R} 6$ & $\mathrm{R} 7$ \\
\hline B. subtilis & -0.09 & $-0.34^{*}$ & 0.03 & $0.55^{*}$ & $0.51^{*}$ & $0.42^{*}$ & $0.33^{*}$ \\
E. faecium & -0.17 & 0.05 & $0.47^{*}$ & $0.47^{*}$ & $0.47^{*}$ & $0.42^{*}$ & 0.28 \\
E. faecalis & 0.02 & $0.35^{*}$ & $0.73^{*}$ & $0.73^{*}$ & $0.73^{*}$ & $0.69^{*}$ & $0.69^{*}$ \\
S. epidermidis & 0.02 & 0.02 & 0.26 & $0.87^{*}$ & $0.98^{*}$ & $0.98^{*}$ & $0.98^{*}$ \\
E. coli & 0.02 & 0.02 & $0.62^{*}$ & $0.98^{*}$ & $0.88^{*}$ & $0.88^{*}$ & $0.98^{*}$ \\
P. multocida & -0.02 & 0.11 & $0.50^{*}$ & $0.78^{*}$ & $0.78^{*}$ & $0.98^{*}$ & $0.98^{*}$ \\
S. bovis & 0.01 & 0.01 & $0.50^{*}$ & $0.42^{*}$ & $0.42^{*}$ & $0.51^{*}$ & $0.38^{*}$ \\
\hline
\end{tabular}

Note: * $\mathrm{P}<0.05$.

Moreover, in the clinically healthy calves, the percentage of this microbial contamination decreased when moving toward the lower respiratory tract, which indicated that the local defense mechanisms of the respiratory tract prevent the colonization of the lower respiratory tract by bacterial pathogens (Caswell, 2014). In healthy calves, the cavity located between the external nasal openings and the choanae presented a decrease in the average percentage of contamination by a factor of $64.3 \%$, which could be attributed to the activity of the mucociliary apparatus, the link between the humoral and cellular local immunity (Cesta, 2006; Alekhin et al., 2018b, 2019). In the nasopharynx and the trachea, the antibacterial effect observed was $100 \%$. This was attributed to the fact that in these regions of the respiratory tract, the defense mechanisms of the mucous membrane were enhanced by the contribution of the complex lymphoid tissue that is rich in immunocompetent cells capable of coordinating the functions of the innate immune system and the acquired immune system (Fukuyama; Nagatake; 
Kiyono, 2009; William, 2013). As a consequence of this, the microorganisms entering the body along with the air were trapped in the upper respiratory tract, while the air free from the vegetative forms of microorganisms entered the lower regions of the respiratory tract. In addition, the results obtained for the samples from the ventral nasal passages at a distance of $7-8 \mathrm{~cm}$ from the external nasal openings in healthy calves reflected the microbiocenosis in the upper respiratory tract with the most common bacteria circulating in the air in the external environment. However, the results obtained for the animals exhibiting the clinical signs of respiratory diseases were highly likely to reflect the microbiocenosis in the upper as well as the lower respiratory tract, which allowed the assessment of the etiology of the respiratory pathology.

The analysis of the changes in the local composition of bacteria in healthy calves revealed that individual bacterial species exhibited different levels of resistance to the protective mechanisms of the respiratory tract of the animals. The most resistant bacterial species were Staphylococcus epidermidis, Bacillus subtilis, and Escherichia coli, while Streptococcus bovis and Enterococci were revealed as the less resistant ones. This difference in resistance levels could be attributed to the innate and/or acquired highly-specialized mechanisms of protection of the epithelial cells in the animals (Ulanova; Gravelle; Barnes, 2009) and the specific ability of the microorganisms to resist these mechanisms (Pel; Pieterse, 2012).

The results of the present study had revealed that unfavorable microclimatic conditions led to the development of disease in $54.1 \%$ of the calves and that the species composition of the bacteria circulating in the upper respiratory tract was the same as that revealed for the sick and healthy calves. Therefore, investigating the role of hematogenous penetration of the pathogen into the lung tissue was excluded from the present study. Bronchopneumonia was caused due to the introduction of airborne bacteria into the lower respiratory tract, probably because of a lower activation of protection as there was no immunological experience of contact with the microflora of the nasal cavity and the nasopharynx. All the isolated bacterial species, with the exception of Bacillus subtilis, participated in the occurrence of pneumonia. Among the species that participated, the most relevant ones were Pasteurella multocida, Streptococcus bovis, and Escherichia coli; these three species had presented increased numbers on the surface of the bronchial mucosa. The development of the respiratory pathology was preceded by a weakening of the mechanisms of protection in the upper respiratory tract. These findings confirmed the speculation that the nasopharyngeal microbiota contributed the most to the microbiota in the lower respiratory tract (Holman et al., 2015).

It is well-recognized that negative microclimatic factors may lead to weakened local immunity, particularly a decreased synthesis of lysozyme, which is produced by monocytes and tissue macrophages (Alekhin et al., 2018a). In the present study, the decrease observed in the level of contamination (APCP) in the nasal cavity of sick animals indicated a weakening of the barrier function of the nasopharynx. Therefore, it was inferred that the dysfunction and/or the pathology must have originated in the region of the choanae and the nasopharynx, and then the dysbiosis of the respiratory tract would have occurred, which created the conditions for the development of bronchitis and pneumonia. Dickson indicated that relative to dysbiosis, the inflammatory process in the lungs is prolonged, with the risk of developing extrapulmonary complications and the transition of the pathology to a chronic form (Dickson et al., 2014; Dickson et al., 2016).

\section{CONCLUSIONS}

Regardless of their overall state of health, the microbiocenosis of the upper respiratory tract does not vary significantly from animal to animal, and no vegetative forms of bacteria are present in the lower parts of the respiratory tract of healthy animals. However, under the effect of unfavorable microclimatic factors, the local protection conferred by the mucous membranes of different regions in the respiratory tract decreases, consequently leading to the stimulation of colonization of the nasal cavity by the bacterial pathogens, followed by the migration of these pathogens to the lower respiratory tract. Therefore, to reduce the renewal activity of the contaminants, it is practically important to introduce measures to restore the local immunity conferred by the mucous membranes of the upper respiratory tract into the course of therapy for bronchitis and pneumonia.

\section{AUTHOR CONTRIBUTION}

Conceptual Idea: Alekhin, Yu.N.; Zhukov M.S.; Methodology design: Alekhin, Yu.N.; Manzhurina, O.A.; Morgunova, V.I.; Data collection: Zhukov M.S., Data analysis and interpretation: Alekhin, Yu.N.; Zhukov M.S.; Manzhurina, O.A.; Morgunova, V.I.; Writing and editing: Alekhin, Yu.N.; Zhukov M.S. 


\section{ACKNOWLEDGEMENTS}

The authors are grateful to Sci-Edit Publications for editing the article in English.

\section{REFERENCES}

ALEKHIN, Y. N. et al. Formation of local protection of the respiratory tract in Holstein calves. Turkish Journal of Veterinary and Animal Sciences, 43(5):656-661, 2019.

ALEKHIN, Y. N. et al. Rheological properties of nasal mucus of calves during periods of development of bronchopneumonia. Journal of Pharmaceutical Sciences and research, 10(12):3458-3460, 2018b.

ALEKHIN, YU. N. et al. Lysozyme activity of nasal secret of calves clinically healthy and the sick with bronchopneumonia. The Veterinarnyy Vrach, 2:38-42, 2018a.

BERGEY, D. H.; KRIEG, N.; HOLT, J. G. Bergey's manual of systematic bacteriology. Baltimore, MD: Williams \& Wilkins, 1984. 2648p.

BROOKS, K. R. et al. Economic effects of bovine respiratory disease on feedlot cattle during backgrounding and finishing phases. The Professional Animal Scientist, 27(3):195-203, 2011.

BRSCIC, M. et al. Prevalence of respiratory disorders in veal calves and potential risk factors. Journal of Dairy Science, 95(5):2753-2764, 2012.

CALVIN, W. B.; BRIAN V. L. Bovine respiratory disease treatment failure: Impact and potential causes. Veterinary Clinics of North America: Food Animal Practice, 36(2):487-496, 2020.

CASWELL, J. L. Failure of respiratory defenses in the pathogenesis of bacterial pneumonia of cattle. Veterinary Pathology, 51(2):393-409, 2014.

CESTA, M. F. Normal structure, function, and histology of mucosa associated lymphoid tissue. Journal of Toxicological Pathology, 34(5):599-608, 2006.

DICKSON, R. P. et al. The microbiome and the respiratory tract. Annual Review of Physiology, 78:481-504, 2016.

DICKSON, R. P.; MARTINEZ, F. J.; HUFFNAGLE, G. B. The role of the microbiome in exacerbations of chronic lung diseases. Lancet, 384(9944):691-702, 2014.

FRANÇA DIAS DE OLIVEIRA, B. A. et al. Determination of bacterial aetiologic factor on tracheobronchial lavage in relation to clinical signs of bovine respiratory disease. Journal of Medical Microbiology, 65(10):1137-1142, 2016.
FRANCO, M. F. et al. Bacteria isolated from the lower respiratory tract of sheep and their relationship to clinical signs of sheep respiratory disease. Pesquisa Veterinária Brasileira, 39(10):796-801, 2019

FUKUYAMA, S.; NAGATAKE, T.; KIYONO, H. Mucosa-associated lymphoid tissue and dynamics of lymphoid cells in the five different compartments in allergic diseases. In: PAWANKAR, R.; HOLGATE, S. T.; ROSENWASSER, L. J. Allergy frontiers: Classification and pathomechanisms. Tokyo: Springer, v. 2, p. 563-601, 2009.

GAETA, N. C. et al. Bacterial pathogens of the lower respiratory tract of calves from Brazilian rural settlement herds and their association with clinical signs of bovine respiratory disease. Pesquisa Veterinária Brasileira, 38(3):374-381, 2018.

HOLMAN, D. B. et al. The nasopharyngeal microbiota of feedlot cattle that develop bovine respiratory disease. Veterinary Microbiology, 180(1-2):90-95, 2015.

LANASPA, M. et al. Respiratory microbiota and lower respiratory tract disease. Expert Review of Antiinfective Therapy, 15(7):703-711, 2017.

MANSOUR, M.; WILHITE, R.; ROWE, J. Guide to ruminant anatomy: Dissection and clinical aspects. Wiley-Blackwell, 2017. 304p.

NATIONAL RESEARCH COUNCIL. Nutrient requirements of beef cattle: Eighth revised edition. National Academy Press, Washington, 2016. 494p.

NICOLA, I. et al. Characterization of the upper and lower respiratory tract microbiota in Piedmontese calves. Microbiome, 5:152, 2017.

PEL, M. J.; PIETERSE, C. M. Microbial recognition and evasion of host immunity. Journal of Experimental Botany, 64(5):12371248, 2012.

PRATELLI, A. et al. Bovine respiratory disease in beef calves supported long transport stress: An epidemiological study and strategies for control and prevention. Research in Veterinary Science, 135:450-455, 2020.

QUINN, P. J. et al. Veterinary microbiology and microbial disease. Wiley-Blackwell, 2011. 912p.

ROBERT, A. S.; DOUGLAS, L. S.; AMELIA, R. W. Bovine respiratory disease: Looking back and looking forward, what do we see?. Veterinary Clinics of North America: Food Animal Practice, 36(2):239-251, 2020. 
ROLAND, L. et al. Influence of climatic conditions on the development, performance, and health of calves. Journal of Dairy Science, 99(4):2438-2452, 2016.

ROY, K. S.; COLLIER, R.J. Regulation of acclimation to environmental stress. Environmental Physiology of Livestock. 1st. John Wiley \& Sons, Chichester, UK, p. 49-54, 2012.

THE COUNCIL OF THE EUROPEAN UNION. Directive93/119/ EC on the protection of animals at time of slaughter or killing. Official Journal of the European Communities, $L$ 340:21-34, 1993.

THE EUROPEAN PARLIAMENT AND THE COUNCIL OF THE EUROPEAN UNION. Directive 2010/63/EU on the protection of animals used for scientific purposes. Official Journal of the European Union, L 276:33-79, 2010.

TIMSIT, E. et al. Respiratory bacterial microbiota in cattle: From development to modulation to enhance respiratory health. Veterinary Clinics of North America: Food Animal Practice, 36(2):297-320, 2020.
ULANOVA, M.; GRAVELLE, S.; BARNES, R. The role of epithelial receptors in recognition of pulmonary pathogens. Journal of Innate Immunity, 1(1):4-17, 2009.

VOLKMANN, N.; SANFTLEBEN, P.; KEMPER, N. Risk factors for respiratory disease in calf rearing. Tierärztl, 70:521-526, 2015.

WALKER, W. L. et al. Characteristics of dairy calf ranches: Morbidity, mortality, antibiotic use practices, and biosecurity and biocontainment practices. Journal of Dairy Science, 95(4):2204-2214, 2012.

WILLIAM, E. P. Fundamental immunology. Philadelphia: Wolters Kluwer Health/Lippincott Williams \& Wilkins, 2013. 1283p.

ZEINELDIN, M.; LOWE, J.; ALDRIDGE, B. Contribution of the mucosal microbiota to bovine respiratory health. Trends in Microbiology, 27(9):753-770, 2019.

ZHUKOV, M. S.; ALEKHIN, YU, N. Funktsional'no-metabolicheskie narusheniya $u$ telyat pri bronkhopnevmonii $v$ period rekonvalestsentsii i ikh farmakoterapevticheskaya korrektsiya. Voronezh, 2018. 134p. 